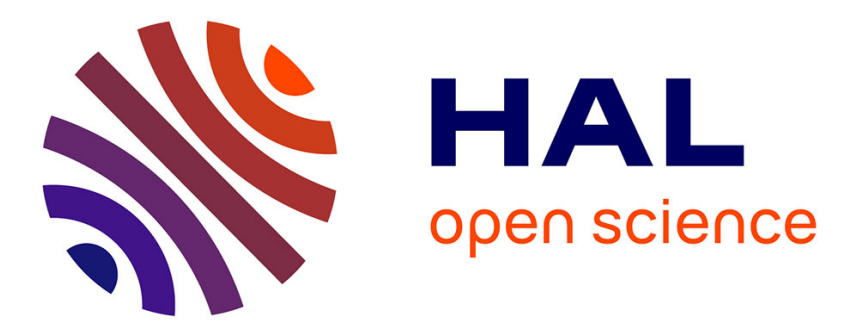

\title{
Toxicity assessment of nanoparticles: impact of physico-chemical properties and adsorption artefacts on biological responses
}

Mélanie Pailleux, Jérémie Pourchez, Philippe Grosseau, Delphine Boudard, Michèle Cottier

\section{To cite this version:}

Mélanie Pailleux, Jérémie Pourchez, Philippe Grosseau, Delphine Boudard, Michèle Cottier. Toxicity assessment of nanoparticles: impact of physico-chemical properties and adsorption artefacts on biological responses. Bulletin du Cancer, 2010, 97, pp.S18. emse-00583184

\section{HAL Id: emse-00583184 \\ https://hal-emse.ccsd.cnrs.fr/emse-00583184}

Submitted on 5 Apr 2011

HAL is a multi-disciplinary open access archive for the deposit and dissemination of scientific research documents, whether they are published or not. The documents may come from teaching and research institutions in France or abroad, or from public or private research centers.
L'archive ouverte pluridisciplinaire HAL, est destinée au dépôt et à la diffusion de documents scientifiques de niveau recherche, publiés ou non, émanant des établissements d'enseignement et de recherche français ou étrangers, des laboratoires publics ou privés. 


\section{Toxicity assessment of nanoparticles: impact of physico-chemical properties and adsorption artefacts on biological responses}

Introduction: In medicine, the uses of nanoparticles (NP) offer new perspectives in imaging (Wagner, 2006), drug delivery (Salmaso, 2004) or radiotherapy (Hainfeld, 2004). However, questions about potential toxic and deleterious effects of nano-structured materials have been raised (Hoet, 2004; Maynard, 2006). Our objective is to develop standardized methods to assess NP toxicity on alveolar macrophages. However, the measurement of biomolecules released in the cell culture supernatants can be modified by their adsorption on the NP. Thus, this adsorption mechanism must be fully understood to avoid misinterpretation of data.

Materials and methods: TNF- $\alpha$ adsorption was evaluated by ELISA kits (R\&D Systems $\left.{ }^{\circledR}\right)$ on aluminum NP. Transmission electron microscopy and X-ray diffraction measurements showed that these nanoparticles had a crystallite size of $10 \mathrm{~nm}$. Laser granulometry emphasized agglomerates of $20 \mu \mathrm{m}$ up to $100 \mathrm{~nm}$. The specific surface area was evaluated to $157 \mathrm{~m}^{2} \cdot \mathrm{g}^{-1}$ by adsorption of $\mathrm{N}_{2}$ and analysis through BET method.

Results: The concentration of biomolecules in cell culture supernatants results of two antagonistic mechanisms: their release by the macrophages and their adsorption on NP surface. We demonstrate a significant adsorption of TNF- $\alpha$ on aluminum NP. Indeed, if $75 \mathrm{pg}$ of TNF is put in contact with $12 \mu \mathrm{g}$ of aluminum NP for 24hours, we measure only $57 \mathrm{pg}$ in supernatants (i.e. $24 \%$ wt of TNF adsorbed on aluminum NP).

Conclusions: We have developed a specific protocol in order to evaluate the organo-mineral interactions in terms of affinity and quantity of biomolecules adsorbed to the aluminum NP at thermodynamic equilibrium. The original results generated lead to quantify the pro-inflammatory, cytotoxic and pro-oxidant effects of the NP used, in the absence of any experimental artefacts due to adsorption of biomolecules to NP surface.

Prospects: The physico-chemical characteristics of NP (chemical composition, crystallographic structure, properties of surface, particles shape ...) have an important influence on their biological activity. We will highlight the correlation between the level of toxicity induced by NP and their physico-chemical characteristics taking into account adsorption artefacts on biological responses.

Keywords: nanoparticles; toxicity; cytokine adsorption 